\title{
ASSESSMENT OF ENERGY TECHNOLOGIES IN ELECTRICITY AND TRANSPORT SECTORS BASED ON CARBON INTENSITY AND COSTS
}

\author{
Dalia ŠTREIMIKIENĖ \\ Kaunas Faculty of Humanities, Vilnius University, \\ Muitines g. 8, 44280 Kaunas, Lithuania \\ Received 13 June 2012; accepted 08 December 2012
}

\begin{abstract}
The aim of the paper is to address the EU policy for achieving low carbon economy by assessing energy technologies in electricity and road transport sector based on costs and impact on climate change and to indicate the most competitive electricity and transport technologies taking into account EU policy targets in GHG emission reduction, utilization of renewable and energy efficiency improvements. The main tasks of the paper are: to develop the multi-criteria framework for comparative assessment of energy technologies by applying MCDM methods for the electricity generation and transport technologies assessment. The interval TOPSIS method is employed in order to tackle the uncertain criteria. The assessment framework allows the comparison of electricity generation technologies and road transport technologies in terms of their GHG emission reduction and economic impacts and facilitates decision making process in energy sector seeking to implement EU energy policies. The main indicators selected for technologies assessment are: private costs and life cycle GHG emissions. The ranking of energy technologies based on private costs and GHG emissions allowed prioritizing these technologies taking into account the lowest GHG emission reduction costs.
\end{abstract}

Keywords: GHG emissions, costs, MCDA assessment, electricity generation technologies, road transport technologies, MCDA.

Reference to this paper should be made as follows: Štreimikiené, D. 2013. Assessment of energy technologies in electricity and transport sectors based on carbon intensity and costs, Technological and Economic Development of Economy 19(4): 606-620.

JEL Classification: Q01, Q48;Q51, Q28, H23. 


\section{Introduction}

The current development process in energy policy is boosted by Commission's Second Strategic Energy Review package in 2008. With regard to the EU energy security and solidarity action plan the Commission figured out five key areas:

- Infrastructure needs and the diversification of energy supplies;

- External energy relations;

- Oil and gas stocks and crisis response mechanisms;

- Energy efficiency;

- Making the best use of the EU's indigenous and renewable energy resources.

The substantial change in the European energy system is expected over the next decades until 2050. All over Europe the Commission estimates challenges and fundamental changes for the energy system between 2020 and 2050. The EU's new energy and environment policy agreed by government leaders in their Council meeting in March 2007 - established a political agenda to tackle three core energy objectives: sustainability, economic competitiveness and security of supply. European leaders reached a historic agreement for the first time to create a common European energy policy.

A triad of specific policies addresses these challenges: first, the 20/20/20 targets of the EU; then, the Second Strategic Energy Review of the European Commission; and finally, plans to liberalise energy markets. In December 2008 the European Parliament adopted a set of legislative documents (the so called EU climate and energy package) for transforming Europe gradually into a low-carbon economy and increasing energy security. An agreement has been reached on legally binding targets, by 2020 :

- to cut GHG emissions by $20 \%$ compared to 1990 ;

- to establish a $20 \%$ share for renewable energy in final energy consumption and the share of biofuels up to $10 \%$ in transport fuels; and

- to achieve a $20 \%$ reduction in energy consumption by 2020 (to improve energy efficiency).

Regarding the reduction of GHG emissions, the package contains an offer to go further and commit to a $30 \%$ cut in the event of a satisfactory international agreement being reached. The European Union is making huge efforts to reduce GHG emissions. EU has prepared the Roadmap for moving to a competitive low-carbon economy in 2050. In this plan the European Commission is looking beyond these 2020 objectives and setting out a plan to meet the long-term target of reducing domestic emissions by 80 to $95 \%$ by mid-century. The EU set targets: to reduce the EU's greenhouse emissions by $80 \%$ by 2050 (compared with 1990 levels) entirely through measures taken within Europe. Intermediate cuts of $25 \%$ by 2020 , $40 \%$ by 2030 and $60 \%$ by 2040 would be needed. Improving energy efficiency, for instance by investing in energy-efficient buildings and transport, can make the biggest contribution to reducing emissions. Clean electricity - produced almost entirely without greenhouse emissions - will also have a major role to play, partly replacing fossil fuels for heating and transport (e.g. electric cars or hybrid cars). Therefore there are 3 pillows for achieving low carbon economy in EU by 2050: clean electricity, clean cars and energy efficiency improvements. 
Another important document - Energy efficiency plan 2011 was adopted by EC. The plan states that the greatest energy saving potential lies in buildings and focuses on instruments to trigger the renovation process in public and private buildings and to improve the energy performance of the components and appliances used in them.

According to the Plan Transport has the second largest potential. The White Paper on Transport is under preparation. Energy efficiency in industry will be tackled through energy efficiency requirements for industrial equipment, improved information provision for SMEs and measures to introduce energy audits and energy management systems. The Commission therefore proposes a two step approach to target setting. As a first stage, Member States are currently setting national energy efficiency targets and programmes. These indicative targets and the individual efforts of each Member State will be evaluated to assess likely achievement of the overall EU target and the extent to which the individual efforts meet the common goal.

A low-carbon economy would have a much greater need for renewable sources of energy, energy-efficient building materials, hybrid and electric cars, 'smart grid' equipment, low-carbon power generation and carbon capture and storage technologies. To make the transition to a low-carbon economy and to reap its benefits such as a lower oil bill the EU would need to invest an additional $€ 270$ billion or $1.5 \%$ of its GDP annually, on average, over the next four decades. The short-term priorities of Roadmap towards low carbon economy and Energy Roadmap 2050: energy efficiency, low carbon technologies in electricity generation and transport.

The main problem is addressing EU 20/20/20 targets by selecting the best technologies in power and transport sector able to help in achieving these targets with the lowest costs. Therefore the main aim of the paper is to address the EU policy for achieving low carbon economy by assessing energy technologies in electricity and road transport sector based on costs and GHG emission reduction potential.

The main tasks of the paper are: to develop the multi-criteria framework for comparative assessment of energy technologies by applying MCDM methods by taking into account the EU energy policy priorities and to apply developed framework for electricity and transport technologies assessment.

\section{The framework for energy technologies assessment}

As there is a wide range of road transport technologies between biofuels and hybrid cars each of them specific with different fuels, selection of the most promising technology becomes very important issue in development of the transport policy. Indeed, it is the selection of the best transport technologies that should be promoted by policy tools in terms of GHG emission and cost reduction. As GHG emissions from road transport are usually provided as the range of values comparative assessment of road transport technologies needs some sophisticated MCDA tools (Hwang, Yoon 1981; Løken 2007; Zavadskas, Turskis 2011; Bauers, Zavadskas 2010; Baležentis et al. 2012a, b; Streimikiene et al. 2011; Kaplinski, Tupenaite 2011; Zvirblis, Buracas 2012). 
The following description of TOPSIS for interval data is presented according to Jahanshahloo et al. (2006). Let us assume there are $i=1,2, \ldots, m$ alternatives evaluated according to $j=1,2, \ldots, n$ criteria. Each criterion can be assigned with respective weight $w_{j}$ such that $\sum_{j} w_{j}=1$. The uncertain response of the $i$-th alternative on the $j$-th criterion is expressed in interval number $\tilde{x}_{i j}=\left[x_{i j}^{l}, x_{i j}^{u}\right]$, where $x_{i j}^{l}$ and $x_{i j}^{u}$ are the lower and the upper bounds respectively of respective response.

The initial decision matrix $\tilde{X}=\tilde{x}_{i j}$ is turned into normalized decision matrix $\tilde{N}=\tilde{n}_{i j}$ in the following way:

$$
\begin{aligned}
& n_{i j}^{l}=x_{i j}^{l} / \sqrt{\sum_{i=1}^{m}\left[\left(x_{i j}^{l}\right)^{2}+\left(x_{i j}^{u}\right)^{2}\right]}, \forall i, j ; \\
& n_{i j}^{u}=x_{i j}^{u} / \sqrt{\sum_{i=1}^{m}\left[\left(x_{i j}^{l}\right)^{2}+\left(x_{i j}^{u}\right)^{2}\right]}, \forall i, j .
\end{aligned}
$$

From now on, the ranges of normalized interval numbers belong to [0, 1]. Furthermore, at this stage they can be multiplied by respective weights.

Consequently, the positive ideal solution $A^{+}$as well as the negative ideal solution $A^{-}$ is obtained as:

$$
\begin{aligned}
& A^{+}=\left\{v_{1}^{+}, v_{2}^{+}, \cdots, v_{n}^{+}\right\}=\left\{\left(\max _{i} n_{i j}^{u} \mid j \in I\right),\left(\min _{i} n_{i j}^{l} \mid j \in J\right)\right\} ; \\
& A^{-}=\left\{v_{1}^{-}, v_{2}^{-}, \cdots, v_{n}^{-}\right\}=\left\{\left(\min _{i} n_{i j}^{l} \mid j \in I\right),\left(\max _{i} n_{i j}^{u} \mid j \in J\right)\right\},
\end{aligned}
$$

where $I$ and $J$ stand for sets of benefit and cost criteria, respectively.

Thereafter, the Euclidean distances from the latter two ideal alternatives are calculated for each $i$-th alternative:

$$
\begin{aligned}
& S_{i}^{+}=\sqrt{\sum_{j \in I}\left(n_{i j}^{l}-v_{j}^{+}\right)^{2}+\sum_{j \in J}\left(n_{i j}^{u}-v_{j}^{+}\right)^{2}} ; \\
& S_{i}^{-}=\sqrt{\sum_{j \in I}\left(n_{i j}^{u}-v_{j}^{-}\right)^{2}+\sum_{j \in J}\left(n_{i j}^{l}-v_{j}^{-}\right)^{2}} .
\end{aligned}
$$

Finally, each alternative is given a closeness coefficient, which is measured as a relative proximity from the negative ideal solution:

$$
\mathrm{CC}_{i}=\frac{S_{i}^{-}}{S_{i}^{+}+S_{i}^{-}}, \forall i
$$

Alternatives with higher values of the closeness coefficient $\left(\mathrm{CC}_{i}\right)$ are attributed with higher ranks. 


\section{MCDA of electricity generation technologies}

The main indicators or criteria for energy technologies assessment will be private costs of energy generation and life cycle GHG emissions. The main electricity generation technologies will be compared and ranked according these criteria. The following energy technologies were selected for assessment in power and heat generation sector: hard coal, natural gas, oil, nuclear and biomass. In power sector just base load technologies were assessed. In this chapter based on recent scientific literature review and results of various EU funded projects the range of life cycle GHG emissions and private costs for the selected electricity generation technologies will be derived.

The principle factors determining the GHG emissions from a fossil fuel power plant is the type of technology (and hence choice of fuel) and its thermal efficiency. In addition, thermal efficiency increases with the load factor (although efficiency reductions can be observed towards achieving full load operation) and therefore GHG emissions from a particular fossil fuel technology will depend on the mode of its operation (e.g. peak load management, base load supply, combined heat and power supply, etc.).

The ranges of life cycle GHG emissions for power and heat generation technologies are presented in Table 1. Life cycle GHG emission ranges (from minimal to maximal values) were presented based on information provided by various sources (Gluch, Baumann 2004; Ekvall 1999; Fritsche, Lim 2006; Weiser 2008; Rhode 2005; Streimikiene 2010, 2013; Streimikiene, Balezentiene 2012). The range of direct $\mathrm{CO}_{2}$ emissions from combustion and total life cycle GHG emissions per technology were calculated in kg/MWh (Table 1).

Table 1. Life cycle GHG emissions of the main energy technologies in power sector

\begin{tabular}{lcccc}
\hline \multirow{2}{*}{ Fuel or energy type } & \multicolumn{2}{c}{$\begin{array}{c}\text { Direct } \mathrm{CO}_{2} \text { emissions } \\
\text { from combustion }\end{array}$} & \multicolumn{2}{c}{ Life cycle $\mathrm{CO}_{2}$ emissions } \\
\cline { 2 - 5 } & $\mathrm{kg} / \mathrm{GJ}$ & $\mathrm{kg} / \mathrm{MWh}$ & $\mathrm{kg} / \mathrm{GJ}$ & $\mathrm{kg} / \mathrm{MWh}$ \\
\hline Nuclear & $2.5 \div 30.3$ & $9 \div 110$ & $2.8 \div 35.9$ & $10 \div 130$ \\
\hline Oil & $126.9 \div 300.7$ & $460 \div 1090$ & $137.9 \div 331.0$ & $500 \div 1200$ \\
\hline Natural gas & $96.6 \div 179.31$ & $350 \div 650$ & $110.3 \div 215.2$ & $400 \div 780$ \\
\hline Hard coal & $193.1 \div 262.1$ & $700 \div 950$ & $206.9 \div 344.8$ & $750 \div 1250$ \\
\hline $\begin{array}{l}\text { Hard coal IGCC } \\
\text { with CO }{ }_{2} \text { capture }\end{array}$ & $52.4 \div 60.7$ & $190 \div 220$ & $38.6 \div 46.9$ & $140 \div 170$ \\
\hline $\begin{array}{l}\text { Large scale wood chips } \\
\text { combustion }\end{array}$ & - & - & $21.0 \div 23.0$ & $76.0 \div 83.3$ \\
\hline $\begin{array}{l}\text { Large scale wood chips } \\
\text { gasification }\end{array}$ & - & - & $6.0 \div 8.0$ & $21.6 \div 29.0$ \\
\hline $\begin{array}{l}\text { Large scale biomass } \\
\text { IGCC } \text { with CO } \text { capture }\end{array}$ & $-39.4 \div-143.5$ & $-505 \div-520$ & $-35.9 \div-41.4$ & $-130 \div-150$ \\
\hline Large scale straw combustion & - & - & $62.0 \div 70.0$ & $223.2 \div 252.0$ \\
\hline $\begin{array}{l}\text { Biomass (wood chips) } \\
\text { CHP large scale }\end{array}$ & - & - & $6 \div 10$ & $21.6 \div 36.0$ \\
\hline $\begin{array}{l}\text { Biomass (wood chips } \\
\text { gasification) CHP small scale }\end{array}$ & - & - & $3 \div 6$ & $10.8 \div 21.6$ \\
\hline
\end{tabular}


As one can see from information provided in Table 1 biomass wood chips gasification technologies have the lowest life cycle GHG emissions followed by wood chips CHP large scale. Hard coal technologies have the highest life cycle GHG emissions followed by oil and natural gas technologies. Hard coal IGCC with $\mathrm{CO}_{2}$ capture technologies have quite low life cycle GHG emission comparable even with Large scale wood chips gasification technologies. Nuclear technologies have lower life cycle GHG emission than some biomass technologies for example large scale straw combustion technologies and large scale wood chips combustion technologies. Biomass technologies with $\mathrm{CO}_{2}$ capture have negative life cycle GHG emissions. Especially high negative GHG emissions are during combustion processes of Biomass IGCC with $\mathrm{CO}_{2}$ capture.

The private costs in EURcnt/kWh are based on the Average Levelised Generating Costs (ALLGC) methodology. The methodology calculates the generation costs (in EuroCents/kWh) on the basis of net power supplied to the station busbar, where electricity is fed to the grid. This cost estimation methodology discounts the time series of expenditures to their present values in 2005, which is the specified base year, by applying a discount rate. According to the methodology used in the IEA study in 2005, the levelised lifetime cost per GWh of electricity generated is the ratio of total lifetime expenses versus total expected outputs, expressed in terms of present value equivalent.

The range of current and long-term private costs (ALLGC) for the same power generating technologies were selected from various information sources (PSI 2003; EUSUSTEL 2007; Mollersten et al. 2003; CASES 2007; PLANETS 2009; Streimikiene 2010). In Table 2 the range of current private costs of the selected power generation technologies is presented.

As one see from information provided in Table 2 the cheapest technologies in long-term perspective are: nuclear and hard coal technologies followed by large scale biomass combustion and biomass CHPs. The most expensive technologies in terms of private costs are: oil and natural gas technologies. Therefore the energy technologies having the lowest life cycle GHG emissions are not the most expensive but not the cheapest one in terms of private costs.

Table 2. Long-term private costs of power generation technologies (2030-2050), EUR/MWh

\begin{tabular}{lcc}
\hline Fuel or energy type & \multicolumn{2}{c}{ Costs, EUR/MWh } \\
\cline { 2 - 3 } & 24 & Max \\
\hline Nuclear & 79 & 42 \\
\hline Oil & 53 & 100 \\
\hline Natural gas & 21 & 60 \\
\hline Hard coal & 40 & 44 \\
\hline Hard coal IGCC with $\mathrm{CO}_{2}$ capture & 35 & 43 \\
\hline Large scale wood chips combustion & 42 & 38 \\
\hline Large scale wood chips gasification & 57 & 49 \\
\hline Large scale biomass IGCC with CO capture $^{2}$ & 44 & 60 \\
\hline Large scale straw combustion & 37 & 48 \\
\hline Biomass (wood chips) CHP large scale & 37 & 60 \\
\hline Biomass (wood chips gasification) CHP small scale & & 60 \\
\hline
\end{tabular}


The multi-criteria assessment of energy technologies in electricity generation sector was performed based on data from Tables 1 and 2 . As one can note, data in table are rather uncertain. Hence, we employed interval TOPSIS method. Note that both of the criteria (life cycle $\mathrm{CO}_{2}$ emissions and costs) are needed to be minimized. Firstly, Eq. (1) was employed to normalize the data (Table 3 ). Thereafter the ideal solutions, $A^{+}$and $A^{-}$, were found (cf. Eq. (2)). The distances of each alternative were found with respect to Eq. (3), whereas closeness coefficients were obtained by employing Eq. (4). Thus, the considered energy generation technologies were prioritized with respect to decreasing value of the closeness coefficient.

Table 3. The normalized interval decision matrix

\begin{tabular}{lcc}
\hline Fuel or energy type & $\begin{array}{c}\text { Life cycle } \mathrm{CO}_{2} \\
\text { emissions }\end{array}$ & Costs \\
\hline Nuclear & {$[0.001,0.015]$} & {$[0.074,0.13]$} \\
\hline Oil & {$[0.057,0.137]$} & {$[0.245,0.31]$} \\
\hline Natural gas & {$[0.046,0.089]$} & {$[0.164,0.186]$} \\
\hline Hard coal & {$[0.085,0.142]$} & {$[0.065,0.136]$} \\
\hline Hard coal IGCC with $\mathrm{CO}_{2}$ capture & {$[0.016,0.019]$} & {$[0.124,0.133]$} \\
\hline Large scale wood chips combustion & {$[0.009,0.009]$} & {$[0.108,0.118]$} \\
\hline Large scale wood chips gasification & {$[0.002,0.003]$} & {$[0.13,0.152]$} \\
\hline Large scale biomass IGCC with CO ${ }_{2}$ capture & {$[-0.015,-0.017]$} & {$[0.176,0.186]$} \\
\hline Large scale straw combustion & {$[0.025,0.029]$} & {$[0.136,0.149]$} \\
\hline Biomass (wood chips) CHP large scale & {$[0.002,0.004]$} & {$[0.115,0.186]$} \\
\hline Biomass (wood chips gasification) CHP small scale & {$[0.001,0.002]$} & {$[0.115,0.186]$} \\
\hline$A^{+}$ & -0.015 & 0.065 \\
\hline$A^{-}$ & 0.142 & 0.310 \\
\hline
\end{tabular}

The electricity generation technologies were assessed in terms of the three weight sets, with first treating both criteria equally, second putting the most of significance on GHG mitigation, and third - on the private costs. Accordingly, the ranking was reiterated three times with different weight sets viz. $(0.5,0.5),(0.75,0.25)$, and $(0.25,0.75)$. Table 4 presents the final results.

As one can note, the best option according to holistic (equal weights) and economic approach is large scale wood chips combustion (rank - 1), whereas large scale biomass IGCC with $\mathrm{CO}_{2}$ capture is the most preferable under the environmental approach thanks to $\mathrm{CO}_{2}$ storage. Nuclear technology was the second best option in terms of holistic and economic approaches, though environmental approach attributed rank of 6 to the latter technology. However, the conventional energy sources - oil, natural gas, and hard coal - received the lowest ranks with respect to all of approaches. Fig. 1 depicts the shifts in closeness coefficients due to weights' alterations. 
Table 4. Closeness coefficients (CC) and ranks for energy technologies

\begin{tabular}{|c|c|c|c|c|c|c|}
\hline \multirow{2}{*}{$\begin{array}{l}\text { Technologies } \\
\text { Nuclear }\end{array}$} & \multicolumn{2}{|c|}{$\begin{array}{l}\text { Equally important } \\
\text { criteria }\end{array}$} & \multicolumn{2}{|c|}{$\begin{array}{l}\text { Environmental } \\
\text { approach }\end{array}$} & \multicolumn{2}{|c|}{$\begin{array}{l}\text { Economic } \\
\text { approach }\end{array}$} \\
\hline & 0.815 & 3 & 0.825 & 6 & 0.793 & 2 \\
\hline Oil & 0.339 & 11 & 0.358 & 10 & 0.272 & 11 \\
\hline Natural gas & 0.493 & 9 & 0.484 & 9 & 0.523 & 10 \\
\hline Hard coal & 0.385 & 10 & 0.286 & 11 & 0.593 & 9 \\
\hline Hard coal IGCC with $\mathrm{CO}_{2}$ capture & 0.774 & 7 & 0.785 & 7 & 0.747 & 3 \\
\hline $\begin{array}{l}\text { Large scale wood chips } \\
\text { combustion }\end{array}$ & 0.833 & 1 & 0.844 & 5 & 0.807 & 1 \\
\hline $\begin{array}{l}\text { Large scale wood chips } \\
\text { gasification }\end{array}$ & 0.817 & 2 & 0.873 & 2 & 0.720 & 4 \\
\hline $\begin{array}{l}\text { Large scale biomass IGCC } \\
\text { with } \mathrm{CO}_{2} \text { capture }\end{array}$ & 0.802 & 4 & 0.921 & 1 & 0.630 & 8 \\
\hline Large scale straw combustion & 0.716 & 8 & 0.727 & 8 & 0.689 & 5 \\
\hline $\begin{array}{l}\text { Biomass (wood chips) CHP } \\
\text { large scale }\end{array}$ & 0.776 & 6 & 0.859 & 4 & 0.663 & 7 \\
\hline $\begin{array}{l}\text { Biomass (wood chips gasification) } \\
\text { CHP small scale }\end{array}$ & 0.780 & 5 & 0.867 & 3 & 0.664 & 6 \\
\hline
\end{tabular}

Equal importance $\quad$ Environmental approach $\quad$ Economic approach

Biomass (wood chips gasification) CHP small scale Biomass (wood chips) CHP large scale Large scale straw combustion Large scale biomass IGCC with $\mathrm{CO} 2$ capture Large scale wood chips gasification Large scale wood chips combustion Hard coal IGCC with CO2 capture Hard coal Natural gas Oil Nuclear

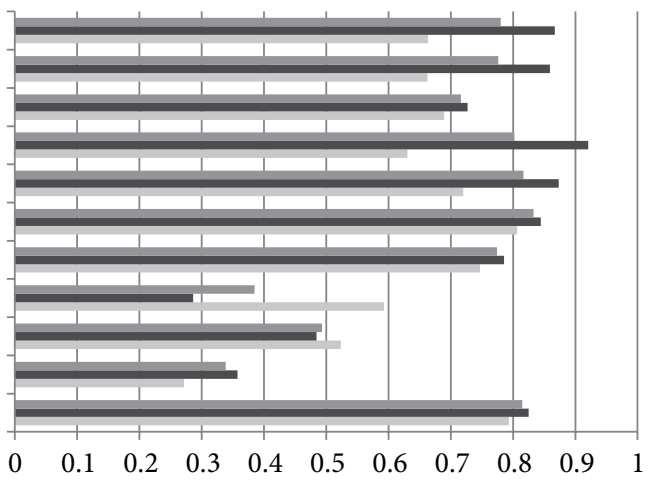

Closeness coefficient

Fig. 1. Impact of different weighting schemes on summarized assessment of energy technologies in electricity generation

The results of analysis imply that the ranking of electricity generation technologies varies across the approaches employed in the analysis. Therefore it is important to quantify the underlying factors of discordance. Thus, Pearson correlation coefficients were obtained to measure the linear relationships between closeness coefficients provided by the three approaches as defined above. Similarly, Spearman rank correlation coefficients were estimated for ranks attributed to the electricity generation technologies according to the three approaches. The results of correlation analysis are presented in Table 5. 
Table 5. Correlation between closeness coefficients (CCs) and ranks across different approaches

\begin{tabular}{lcccc}
\hline Approaches & \multicolumn{2}{c}{ Equally important criteria } & \multicolumn{2}{c}{ Environmental approach } \\
\cline { 2 - 5 } & CCs & Ranks & CCs & Ranks \\
\hline Environmental approach & 0.98 & 0.80 & & \\
\hline Economic approach & 0.84 & 0.77 & 0.72 & 0.39 \\
\hline
\end{tabular}

It is evident that the holistic approach-based ranking is related to the environmental approach-based one at a higher extent if compared to the linkage between holistic approach and economic approach. The lowest values of the correlation coefficients were observed between environmental and economic approaches. This finding suggests that GHG mitigation and energy costs are the two conflicting criteria. The economic incentive schemes therefore are rather important for sustainable energy development.

\section{MCDA of transport technologies}

The main indicators or criteria for energy technologies assessment will be private costs of energy generation and life cycle GHG emissions. The main transport technologies will be compared according these indicators and ranked.

The data on life cycle GHG emissions for specific fuel cycles is necessary seeking to assess external costs of GHG emissions for different energy technologies using information about $\mathrm{CO}_{2}$ prices over the time and space delivered by various models by running policy scenarios. Life cycle $\mathrm{CO}_{2}$ emissions from power an transport sector depend strongly upon details of supply chain, production techniques, forestry and agriculture practices, transport distance, etc. The range of life cycle GHG emissions of transport technologies in g/vehicle km were obtained by gathering data on GHG emissions from transport sector from various sources and evaluating direct $\mathrm{CO}_{2}$ emissions from combustion and total life cycle GHG emissions for specific transport technologies (Litman 2008; Bauen 2007; Woods et al. 2005; Zah et al. 2007; Samaras, Meisterling 2008; Moawad et al. 2009; Ecolane Transport Consultancy 2006; Maclean, Lave 2003; Rajagopal, Zilberman 2008; EPA 2005; Harrington, McConnell 2003; Farell et al. 2006; EPRI 2007; Gallo 2011). The life cycle GHG emissions for road transport technologies are presented in Table 6.

Fuel GHG intensity is the key factor which represents the net lifecycle emissions impact associated with the consumption of a unit of fuel. Sometimes termed a fuel's "carbon footprint", it can be expressed in units of grams of carbon dioxide-equivalent per megajoule $\left(\mathrm{gCO}_{2} \mathrm{eq} / \mathrm{MJ}\right)$ of energy delivered to vehicles or other transportation equipment.

The range of current private costs of road transport technologies were evaluated in EURcnt/vehicle $\mathrm{km}$ based on information about costs of fuels provided by various data sources (Bauen 2007; Woods et al. 2005; Zah et al. 2007; Samaras, Meisterling 2008; Gross et al. 2009; Schipper 2011; Rajagopal, Zilberman 2008; Arslan et al. 2010; Harrington, McConnell 2003; Lipman, Delucchi 2006; Moawad et al. 2009; MacLean, Lave 2003) are presented in Table 7 . The price of gasoline and diesel is based on cost of crude oil ca $\$ 50 /$ barrel (FOB Gulf price). These costs for biofuels vary widely depending on location for existing bioethanol and biodiesel technologies. 
Table 6. Life cycle GHG emissions of road transport technologies

\begin{tabular}{lc}
\hline Life cycle GHG emissions of the momotor vehicles & in g/vehicle $\mathrm{km}$ \\
\hline HEV & $180-192$ \\
\hline PHEV 30 & $126-183$ \\
\hline PHEV 60 & $104-181$ \\
\hline PHEV 90 & $96-183$ \\
\hline Petrol & $227.4-307.6$ \\
\hline Diesel & $243.0-251.7$ \\
\hline Bioethanol from sugar beet & $103.5-120.2$ \\
\hline Bioethanol from wheat & $43.5-75.5$ \\
\hline Biodiesel from rapeseed & $109.1-120.2$ \\
\hline Biodiesel from waste vegetable oil & $30.8-41.9$ \\
\hline
\end{tabular}

Table 7. Private costs of motor vehicle in 2020, EURcnt/kWh

\begin{tabular}{|c|c|c|c|c|c|c|c|c|}
\hline & \multicolumn{3}{|c|}{ Average fuel costs } & \multicolumn{3}{|c|}{ Average electricity cost } & \multirow[b]{2}{*}{ 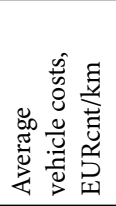 } & \multirow[b]{2}{*}{  } \\
\hline & 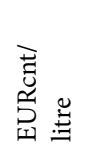 & 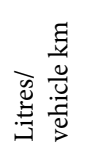 & 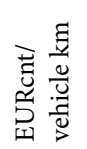 & 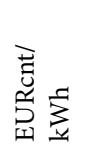 & 吾 & 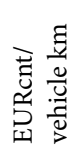 & & \\
\hline $\mathrm{HEV}$ & 50 & 0.057 & 2.85 & - & - & - & 9.0 & 11.9 \\
\hline PHEV 30 & 50 & 0.042 & 2.1 & 8 & 0.2 & 2.4 & 9.1 & 12.8 \\
\hline PHEV 60 & 50 & 0.03 & 1.5 & 8 & 0.25 & 3.0 & 9.9 & 13.4 \\
\hline PHEV 90 & 50 & 0.02 & 1.0 & 8 & 0.3 & 3.6 & 12.2 & 15.6 \\
\hline Petrol & 50 & 0.08 & 4.0 & - & - & - & 7.2 & 11.2 \\
\hline Diesel & 40 & 0.08 & 3.2 & - & - & - & 7.0 & 10.2 \\
\hline Bioethanol from sugar beet & 70 & 0.08 & 5.6 & - & - & - & 7.2 & 12.8 \\
\hline Bioethanol from wheat & 90 & 0.08 & 7.2 & - & - & - & 7.2 & 14.4 \\
\hline Biodiesel from rapeseed & 60 & 0.08 & 4.8 & - & - & - & 7.0 & 11.8 \\
\hline $\begin{array}{l}\text { Biodiesel from waste } \\
\text { vegetable oil }\end{array}$ & 80 & 0.08 & 6.4 & - & - & - & 7.0 & 13.4 \\
\hline
\end{tabular}

The multi-criteria assessment of energy technologies for road transport technologies was performed based on data from Tables 6 and 7. As one can note, data in table are rather uncertain. Hence, we employed interval TOPSIS method. Firstly, Eq. (1) was employed to normalize the data. Thereafter the ideal solutions were found (cf. Eq. (2)). The distances of each alternative were found with respect to Eq. (3), whereas closeness coefficients were obtained by employing Eq. (4). Thus, the considered road transport technologies were prioritized with respect to decreasing value of the closeness coefficient.

The road transport technologies were assessed in terms of the three weight sets, with first treating both criteria equally, second putting the most of significance on GHG mitigation, and third - on the private costs. Accordingly, the ranking was reiterated three times with different weights. Table 8 presents the final results. 
Table 8. Closeness coefficients (CC) and ranks for energy technologies

\begin{tabular}{lcccccc}
\hline Technologies & \multicolumn{2}{c}{$\begin{array}{c}\text { Equally } \\
\text { important criteria }\end{array}$} & \multicolumn{2}{c}{$\begin{array}{c}\text { Environmental } \\
\text { approach }\end{array}$} & \multicolumn{2}{c}{$\begin{array}{c}\text { Customer-first } \\
\text { approach }\end{array}$} \\
\hline HEV & CC & Rank & CC & Rank & CC & Rank \\
\hline PHEV 30 & 0.455 & 8 & 0.443 & 8 & 0.554 & 5 \\
\hline PHEV 60 & 0.543 & 7 & 0.544 & 7 & 0.534 & 7 \\
\hline PHEV 90 & 0.569 & 5 & 0.575 & 6 & 0.512 & 8 \\
\hline Petrol & 0.559 & 6 & 0.580 & 5 & 0.402 & 10 \\
\hline Diesel & 0.261 & 10 & 0.227 & 10 & 0.458 & 9 \\
\hline Bioethanol from sugar beet & 0.299 & 9 & 0.232 & 9 & 0.561 & 4 \\
\hline Bioethanol from wheat & 0.685 & 4 & 0.695 & 3 & 0.609 & 3 \\
\hline Biodiesel from rapeseed & 0.791 & 2 & 0.850 & 2 & 0.553 & 6 \\
\hline Biodiesel from waste vegetable oil & 0.690 & 3 & 0.690 & 4 & 0.696 & 1 \\
\hline
\end{tabular}

As one can note, the best option according to holistic (equal weights) and environmental approach is biodiesel from waste vegetable oil, whereas customers would prefer biodiesel from rapeseed. Indeed, the first two approaches suggest bioethanol and biodiesel as the most preferable fuels. The customer-first approach, however, graduated diesel to the fourth place and subsequently put bioethanol from wheat into the sixth place. Fig. 2 depicts the shifts in closeness coefficients due to weights' alterations.

As Fig. 2 exhibits, diesel, petrol, and HEV were those road transport technologies preferred by customers due to lower private costs. At the other end of spectrum, there were biodiesel from waste vegetable oil, bioethanol from wheat, and PHEV 90 specific with lower contribution to GHG emission.

- Customer approach $\quad$ Environmental approach $\quad \square$ Equal weights

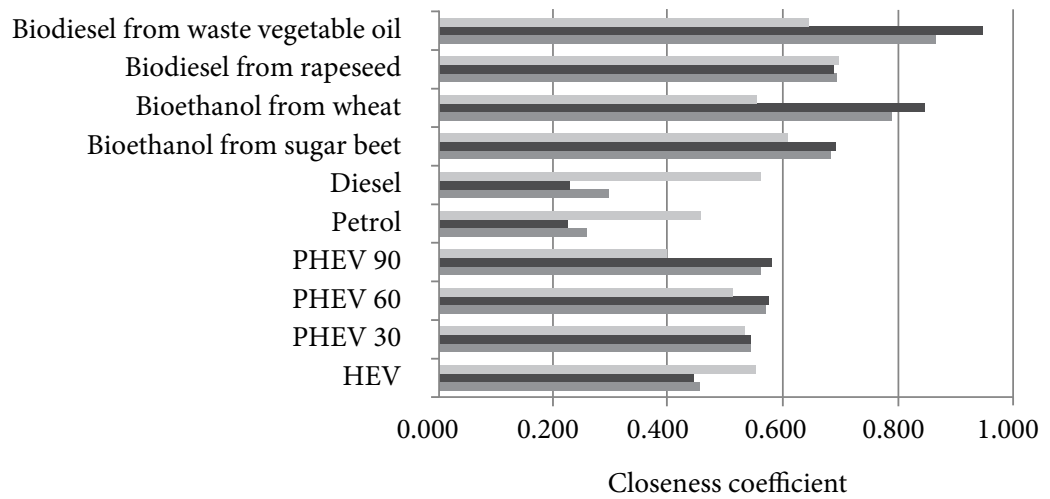

Fig. 2. Impact of different weighting schemes on summarized assessment of energy technologies 
Other options as eco-driving and better roads have also significant impact on GHG emissions from road transport (Knudsen, Bang 2007; Raborn 2011) however these options were left out of the scope of this paper.

\section{Conclusions}

1. The framework for energy technologies assessment and ranking based on EU energy policy priorities is developed. The main assessment and ranking criteria for energy technologies are: life-cycle GHG emissions and private costs. The transport and electricity generation technologies were assessed by applying the same tools.

2. Multi-criteria analysis of electricity generation technologies encompassing life cycle GHG emissions and private costs was carried out in terms of the three different approaches: 1) holistic approach considered both of the criteria were equally important; 2) environmental approach placed the highest significance on GHG emission reduction; and 3) economic approach first of all aimed at cost mitigation.

3. The holistic approach suggests large scale wood chips combustion, large scale wood chips gasification, and nuclear power, in that order, are the three most sustainable technologies. Hard coal IGCC with $\mathrm{CO}_{2}$ capture was also supported by the economic approach. The environmental approach identified large scale wood chips gasification, large scale biomass IGCC with $\mathrm{CO}_{2}$ capture, and small scale biomass (wood chips gasification) CHP as the most suitable technologies. The carried out analysis indicated that certain economic incentives are needed to ensure sustainable energy development.

4. Analysis of life cycle GHG emissions and private costs of the main road transport technologies performed in the paper derived that road transport technologies based on biodiesel from waste vegetable oil have the lowest life cycle GHG emission followed by technologies using bioethanol from wheat. Petrol based transport technologies have the highest life cycle GHG emissions followed by diesel technologies. The most expensive in terms of fuel costs are bioethanol transport technologies and the cheapest are transport technologies based on petrol and diesel. Therefore the transport technologies having lowest life cycle GHG emission are among the most expensive in terms of fuel costs. Therefore the policy oriented ranking of transport technologies taking into account these two main issues into account allow to develop new transport policies and to promote the best ranked technologies.

5. The multi-criteria assessment of energy technologies for road transport was carried out. Hence, road transport technologies were ranked with respect to GHG emission and private costs. In order to check the sensitivity of the results, the three weight sets were defined: 1) both of the criteria were considered equally important (i.e. no weights were defined); 2 ) for environmental approach the most of significance, namely 80 per cent, was given to $\mathrm{CO}_{2}$ emission reduction; 3) for consumer-oriented approach the greatest significance of 80 per cent was attributed to the private costs criterion. The analysis showed that bioethanol from sugar beet, biodiesel from rapeseed, and biodiesel from waste vegetable oil are the most preferable technologies and have to be further promoted by policy tools. 
6. Comparative assessment of road transport technologies based on lifecycle GHG emission and private costs presents just one issue of climate change mitigation policy related with promotion of advanced road transport technologies having the lowest costs. Other policies, i.e. improvement of road infrastructure, traffic management, eco-driving, spatial planning etc. can significantly reduce GHG emissions from road transport.

\section{References}

Arslan, R.; Ulusoy, Y.; Tekin, Y.; Sürmen, A. 2010. An evaluation of the alternative transport fuel policies for Turkey, Energy Policy 38(6): 3030-3037. http://dx.doi.org/10.1016/j.enpol.2010.01.042

Baležentis, A.; Baležentis, T.; Brauers, W. K. M. 2012b. Personnel selection based on computing with words and fuzzy MULTIMOORA, Expert Systems with Applications 39(9): 7961-7967. http://dx.doi.org/10.1016/j.eswa.2012.01.100

Baležentis, A.; Baležentis, T.; Misiūnas, A. 2012a. An integrated assessment of Lithuanian economic sectors based on financial ratios and fuzzy MCDM methods, Technological and Economic Development of Economy 18(1): 34-53. http://dx.doi.org/10.3846/20294913.2012.656151

Bauen, A. 2007. Reporting the carbon intensity of biofuels under the RTFO. London, UK.

Bauers, W. K. M.; Zavadskas, E. K. 2010. Robustness in the Multimoora model: the example of Tanzania, Transformation in Business \& Economics 9(3): 67-83.

CASES. 2007. EU Framework 6. Costs assessment of sustainable energy systems. Final Report.

Ecolane Transport Consultancy. 2006. Life cycle assessment of vehicle fuels and technologies. Final Report, London: Boroughof Camdem.

Ekvall, T. 1999. Key methodological issues for life cycle inventory analysis of paper recycling, Journal of Cleaner Production 7: 281-294 http://dx.doi.org/10.1016/S0959-6526(99)00149-3

EPA. 2005. Average carbon dioxide emissions resulting from gazoline and diesel fuel. Office of Transportation and Air Quality, EPA.

EPRI. 2007. Environmental assessment of plug-in-hybrid electric vehicles, Volume 2: United States air quality analysis based on AEO-2006 assumptions for 2030. Palo Alto, CA: EPRI.

EUSUSTEL. 2007. EU Framework 6. European sustainable electricity, comprehensive analysis of future European demand and generation of European electricity and its security of supply. Final technical report.

Farrell, A. E.; Plevin, R. J.; Turner, B. T.; Jones, A. D.; O’Hare, M.; Kammen, D. M. 2006. Ethanol can contribute to energy and environmental goals, Science 311: 506-508. http://dx.doi.org/10.1126/science.1121416

Fritsche, U. R.; Lim, S. S. 2006. Comparison of GHG emissions and abatement costs of nuclear and alternative energy options from a life cycle perspective. Oko-Institute.

Gallo, M. 2011. A fuel surcharge policy for reducing road traffic greenhouse gas emissions, Transport Policy 18(2): 413-424. http://dx.doi.org/10.1016/j.tranpol.2010.11.003

Gluch, P.; Baumann, H. 2004. The life cycle costing (LCC) approach: a conceptual discussion of its usefulness for environmental decision-making, Building and Environment 39: 571-580.

http://dx.doi.org/10.1016/j.buildenv.2003.10.008

Gross, R.; Heptonstall, P.; Anable, J.; Greenacre, P. 2009. What policies are effective at reducing carbon emissions from surface passenger transport? - a review of interventions to encourage behavioural and technological change. UKERC.

Harrington, W.; McConnell, V. 2003. Motor vehicles and the environment. REFR report. 
Hwang, C. L.; Yoon, K. 1981. Multiple attribute decision making methods and applications. Berlin: Springer-Verlag. http://dx.doi.org/10.1007/978-3-642-48318-9

Jahanshahloo, G. R.; Hosseinzadeh, H.; Lotfi, F.; Izadikhah, M. 2006. An algorithmic method to extend TOPSIS for decision-making problems with interval data, Applied Mathematics and Computation 175(2): 1375-1384. http://dx.doi.org/10.1016/j.amc.2005.08.048

Kaplinski, O.; Tupenaite, L. 2011. Review of the multiple criteria decision making methods, intelligent and biometric systems applied in modern construction economics, Transformation in Business \& Economics 10 (1): 166-181.

Knudsen, T.; Bang, B. 2007. Environmental consequences of better roads. SINTEF Technology and Society.

Lipman, T. E.; Delucchi, M. A. 2006. A retail and life cycle cost analysis of hybrid electric vehicles, Transportation Research Part D: Transport and Environment 11(2): 115-132.

http://dx.doi.org/10.1016/j.trd.2005.10.002

Litman, T. 2008. Generated traffic and induced travel. Victoria Transport Policy Institute.

Løken, E. 2007. Use of multicriteria decision analysis methods for energy planning problems, Renewable and Sustainable Energy Reviews 11: 1584-1595. http://dx.doi.org/10.1016/j.rser.2005.11.005

MacLean, H. L.; Lave, L. B. 2003. Life cycle assessment of automobile/fuel options, Environmental Science \& Technology 37(23): 5445-5452. http://dx.doi.org/10.1021/es034574q

Moawad, A.; Singh, G.; Hagspiel, S.; Fellah, M.; Rousseau, A. 2009. Impact of real world drive cycles on PHEV fuel efficiency and cost for different power train and batter characteristics, World Electric Vehicle Journal 3: 1-10.

Mollersten, K.; Yan, J.; Moreira, J. R. 2003. Potential market niches for biomass energy with CO2 capture and storage-opportunities for energy supply with negative CO2 emissions, Biomass and Bioenergy 25: 273-285. http://dx.doi.org/10.1016/S0961-9534(03)00013-8

PLANETS. 2009. EU Framework 7. Probabilistic long term assessment of new energy technology scenarios. Deliverable No. 9. Report on Technology assessment-I.

PSI. 2003. Integrated assessment of sustainable energy systems in China - The China Energy Technology Program (CETP) - A framework for decision support in the electric sector of shandong province. Eliasson, B.; Lee, Y. Y. (Eds.).

Raborn, C. 2011. Transportation and climate policy summary: Green house gas emissions resulting from different infrastructure spending levels. Nicolas Institute, Duke University.

Rajagopal, D.; Zilberman, D. 2008. The use of environmental life-cycle analysis for evaluating biofuels. Gianini Foundation of Agricultural Economics. USA: University of California.

Rhode, S. 2005. Engineering economic analysis of biomass IGCC with carbon capture and storage, Biomass and Bioenergy 29: 440-450. http://dx.doi.org/10.1016/j.biombioe.2005.06.007

Samaras, C.; Meisterling, K. 2008. Life cycle assessment of greenhouse gas emissions from plug-in hybrid vehicles: implications for policy, Environmental Science and Technology 42: 3170-3176. http://dx.doi.org/10.1021/es702178s

Schipper, L. 2011. Automobile use, fuel economy and CO2 emissions in industrialized countries: encouraging trends through 2008?, Transport Policy 18(2): 358-372.

http://dx.doi.org/10.1016/j.tranpol.2010.10.011

Streimikiene, D. 2010. Comparative assessment of future power generation technologies based on carbon price development, Renewable and Sustainable Energy Reviews 14: 1283-1292. http://dx.doi.org/10.1016/j.rser.2009.12.001

Streimikiene, D.; Balezentiene, L. 2012. Assessment of electricity generation technologies based on GHG emission reduction potential and costs, Transformation in Business \& Economics 11(2A): 333-344.

Streimikiene, D.; Mikalauskiene, A.; Barakauskaite-Jakubauskiene, N. 2011. Sustainability assessment of policy scenarios, Transformation in Business \& Economics 10(2): 168-184. 
Streimikiene, D. 2013. Assessment of road transport technologies based on GHG emission reduction potential and costs, Transformation in Business \& Economics 12(2): 138-147.

Weiser, D. 2008. A guide to life-cycle GHG emissions from electric supply technologies. Vienna: IAEA.

Woods, J.; Brown, G.; Estrin, A. 2005. Bioethanol greenhouse gas calculator - user's guide. London: Imperial College.

Zah, R.; Böni, H.; Gauch, M.; Hischier, R.; Lehmann, M.; Wäger, P. 2007. Life cycle assessment of energy products: environmental assessment of biofuels. Bern: Empa.

Zavadskas, E. K.; Turskis, Z. 2011. Multiple criteria decision making (MCDM) methods in economics: an overview, Technological and Economic Development of Economy 17(2): 397-427. http://dx.doi.org/10.3846/20294913.2011.593291

Zvirblis, A.; Buracas, A. 2012. Multiple criteria assessment of the country's knowledge economy determinants, Transformation in Business \& Economics 11 (3): 124-137.

Dalia ŠTREIMIKIENE் is a senior research fellow at the Social Cultural Institute of Kaunas Faculty of Humanities, Vilnius University. She holds PhD in Economics and is a Professor and a Leading Research Associate at Vilnius University Kaunas Faculty of Humanities. She has experience in various projects related to sustainable development, environmental and climate change mitigation policies. She also has experience in consumer behaviour and business ethics. The main area of her research is sustainability assessment of policies, technologies and products in energy field, development of indicator frameworks for sustainability assessment. 